\title{
Kocaeli İlinde Görev Yapan Öğretmenlerin Müzik Dinleme Alışkanlıklarının İncelenmesi
}

\author{
Gülşah GÖKÇEN ${ }^{1}$, Ümit Kubilay CAN² ve Hakan BAĞCI ${ }^{3}$
}

$\ddot{\mathrm{O} z}$

$\mathrm{Bu}$ araştırmada Kocaeli ilinde görev yapan öğretmenlerin müzik dinleme alışkanlıklarının incelenmesi amaçlanmaktadır. Bu amaç doğrultusunda dinlenilen müzik türleri, kişisel albüm arşivleri, dijital ortam albüm arşivleri, dinledikleri müziklerde etkilendikleri unsurlar, müzik dinleme araçları, dinleme ortamları, çalgı çalma durumlarının neler olduğu sorgulanmaktadır. Bu doğrultuda araştırmacılar tarafindan hazırlanan ve öğretmenlerin müzik dinleme alışkanllklarını saptamak için 12 sorudan oluşan "Öğretmenlerin müzik dinleme alışkanlıkları" anketi uygulanmıştır. Araştırma, 2020-2021 eğitim, öğretim ylı Kocaeli’de görev yapan 421 öğretmenin katullımılla gerçekleşmiştir. Araştırma sonuçlarına göre; öğretmenler ilk sırada Pop Müzik dinlemeyi, ikinci sırada Türk Halk Müziği dinlemeyi tercih etmektedirler. Öğretmenlerin müzik dinlemek için gelişen teknoloji ile dijital ortamlardan yararlandıkları ve telefonların birer müzik çalara dönüşmesiyle en çok akıllı telefonları tercih ettikleri görülmüştür. Çaldıkları çalgıların seçiminde, popüler çalgıları tercih ettikleri ve dinledikleri müzik türlerinde kullanılan çalgılar olduğu görülmüş̧ür.

Anabtar Kelimeler: Müzik Dinleme Alışkanlı̆̆1, Müzik tercihi, Öğretmenlik Mesleği, Müzik Eğitimi, Müzik

\section{Examination of Music Listening Habits of Teachers Working in Kocaeli Province}

\begin{abstract}
In this research, it is planned to examine the music listening habits of the teachers working in Kocaeli. For this purpose, the type of music listened to, personal albums, digital media album archives, the factors that are affected by the music they listen to, music listening tools, listening environments, and instrument playing situations are questioned. In this direction, "Teachers' music listening habits" questionnaire consisting of 12 questions was applied by the researchers to rank and determine the music listening habits of the teachers. The research was carried out with the participation of 421 teachers from working in Kocaeli for the 2020-2021 academic years. According to the results of the research, teachers prefer to listen to Pop Music in the first place and to Turkish Folk Music in the second place. It has been observed that teachers use the developing technology and digital environments to listen to music, and they prefer smart phones most as phones turn into music players. In the selection of the instruments they play, it has been observed that they prefer popular instruments and the instruments used in the music genres they listen to.
\end{abstract}

Key Words: Habit of Listening to Music, Music Preference, Teaching Profession, Music Education, Music

\section{Atıf İçin / Please Cite As:}

Gökçen, G., Can, Ü. K. ve Bağc1, H. (2021). Kocaeli ilinde görev yapan öğretmenlerin müzik dinleme alıskanliklarının incelenmesi. Manas Sosyal Araştrmalar Dergisi, 10(4), 2123-2136.

Geliş Tarihi / Received Date: 06.02.2021

Kabul Tarihi / Accepted Date: 24.05.2021

\footnotetext{
1 Yüksek Lisans Öğrencisi - Kocaeli Üniversitesi Güzel Sanatlar Fakültesi Müzik Bölümü / Kocaeli - gulsah.gokcn@gmail.com, ORCID: 0000-0003-4998-9027

2 Doç. Dr. - Kocaeli Üniversitesi Güzel Sanatlar Fakültesi Müzik Bölümü / Kocaeli - kubilay.can@kocaeli.edu.tr,

(iD) ORCID: 0000-0001-9197-2240

${ }^{3}$ Doç. Dr. - Kocaeli Üniversitesi Güzel Sanatlar Fakültesi Müzik Bölümü / Kocaeli - hakan.bagci@kocaeli.edu.tr,

iD ORCID: 0000-0001-5312-3168
} 


\section{Giriş}

Müzik, yaşantımızın her anında (Öz, 2001, s. 103; Flowers ve Murphy, 2001, s. 26; İmik, 2007, s. 3) var olan işlevsel bir niteliktir. En önemli işlevsellik duygularımızın aktarımıdır. Duygularımızı ifade etme biçimimiz olan müzik (Güleç, 2009, s. 366), konuşamadığımız, paylaşamadığımız bütün duygularımızı yansıtırken, aynı zamanda yaşam içinde disipline olmamızı sağlar. Doğup, büyüdüğümüz çevredeki müziğimizle evrilerek (İmik, 2007, s. 36), aynı zamanda farklı çevrelerle de etkileşim halinde olup bir takım deneyimler elde ederiz. Bu deneyimler sonucu yaşantımızı şekillendirip, davranışlar geliştiririz.

İnsan yaşamında müziğin işlevleri bireysel, toplumsal, kültürel, ekonomik ve eğitimsel olmak üzere beş ana kümede toplanır (Uçan, 2005, s. 11; İmik, 2007, s. 4). Müziğin bireysel işlevi, müzik yolu ile kişinin yaşantısında gerçekleştirdiği birtakım değişimlerdir. Müzik kişinin kendisindeki yeteneğin farkına varmasına, kendini tanımasına, kendine güveninin artmasına, kendisi için sağlıklı ve yaşamdan lezzet alabileceği bir hayat kurmasına olanak sağlar. Kişi bireysel anlamda kendini müzik yolu ile gerçekleştirdiğinde, topluma faydalı olur, dayanışma ve paylaşım içinde olur. Bununla birlikte toplumsal işlevi bağlamında, birey aynı zamanda kendi kültürünü etkileşim ve paylaşım içinde olduğu bireylere aktararak (Erdal, 2007, s. 292), onların da kültürünü kazanır. Kültürel kimliğin ve kişiliğin oluşması, korunması, geleceğe aktarımı açısından müzik önemli bir yere sahiptir. Müziğin ekonomik işlevi, bireylerin, toplumların müzik ihtiyaçları yönünden ele alındığında üretim, tüketim ve dağıtım alanı olma kapsamında müziğin pazarlanması, satışı, aktarımı gibi maddi boyutu düşünülmelidir. Müziğin eğitim işlevi ise bireyin davranışlarında kendi yaşantısı yoluyla müziğin gücünden yararlanılarak istendik davranışlar oluşturma (Erdal, 2007, s. 288) sürecidir. Müziğin eğitimsel etki ve işlevi; eğitim boyutu olma, eğitim aracı olma ve eğitim yönetimi olması ele alındığında öğretmenlerin ve öğrencilerin birbirleri ile etkileşim halinde olmaları, müziğin gücünden yararlanılarak eğitim sürecine katkıda bulunulması bakımından önem taşımaktadır.

İnsan, yaşamı boyunca müzikle her zaman iç içedir (Özen, 2016, s. 10). Planlı ya da plansız bir şekilde müzik dinleme eylemi ile karşılaşmaktadır. Dinlenilen müziklerin içinden yaşantı ve edinilen deneyimlere göre beğeni oluşturmaktadır. Müzik beğenisi kişinin duyduğu müzikleri yaşantısı ile ilişkilendirmesi, müziği anlamlandırarak, içselleştirerek, yorumlayacak şekilde değerlendirmesi müzik dinleme alıskanllğında düzen oluşturur. Bu durumda, olumlu istendik davranışa ulaşmak için eğitimin gücünden yararlanılabilir. Bireylerin yaşantılarında etkili olan müzik eğitimi, müzik öğretmeninin görev ve sorumluluğunda olduğu gibi branş öğretmenlerini de kapsamalıdır. Branş öğretmenleri eğitim öğretim içerisinde branşları ile sanat arasında bağlantı kurarak müzik eğitimi ile ilgili bazı temel alışkanlıkları öğrencilere kazandırabilir. Müzik eğitiminin alt yapısının oluşum süreci aile ve sonrasında öğretmenlere bağlıdır.

Toplumun en önemli bireyleri öğretmenler, öğrencilerin yetiştirilmesinde en güçlü dinamizmi oluşturmaktadırlar. Ailede müzik kültürünü kazanan öğrenciler, edindiği kültürün gelişimini eğitim sürecinde öğretmenlerin rehberliğinde sağlam temellerle şekillendirip tüm yaşamları üzerinde kurgulayabilirler. Gelecekte müziğin yaşantıya dahil olması, yaşamın bir parçası haline gelmesi küçük yaşlarda edinilen deneyimlere ve eğitim ortamına bağlıdır. Öğrencilere nasıl müzik dinleneceğini öğretmek, hassas dinleyiciler olabilmeleri ve dinlemenin keyfini çıkarabilmeleri açısından son derece önem taşımaktadır (Anderson, 2016). Eğitim ortamında müziği deneyimleyen bireyler, yaşamlarında müziği sürdürmektedirler (Flowers ve Murphy, 2001, s. 30).

Toplumda müzik beğenisi oluşturmak sadece müzik öğretmenlerini değil, bütün branş öğretmenlerini kapsamalıdır. Farklı branşlardaki öğretmenler, müziği tüm yaşantılarına dahil ederek kültür aktarımında rol oynamalıdır. Öğretmenlerin kişisel ve mesleki nitelikleri, donanımları öğrencilerin hem okula, hem de derslere karşı geliştirecekleri tutumu etkilemektedir. Öğretmenlerin öğrencilerinin yaşantılarında etkili olabilmeleri için alanlarına hâkim olmaları, mesleki yönden donanıma sahip olmaları ve en önemlisi öğrencileri ile iletişim kurabilme becerilerinin çok güçlü olması gerekir. Bununla birlikte öğretmenler, yaşadıkları toplumun sosyal ve kültürel özelliklerini bilmeli ve bu değerleri aynı zamanda öğrencilerine aktarabilmelidirler. Müzik eğitimi alan farklı branşlardaki öğretmenler, müzik eğitiminin verdiği kültürel zenginlikle toplumun çok yönlü gelişim göstermesini sağlayabilir. Müziğin eğitimsel işlevi, öğrencilerin genel eğitiminde etkili ve verimli olmakla birlikte, onlara müziği sevdirmek, müziğe olan ilgilerini arttırmak, onların müzik dinleme ve eleştirebilme becerilerini geliştirmek, beğeni düzeylerini belirlemek (Kılıç, 2016, s. 361) ve yükseltmek bakımından eğitimde önemli rol oynar. Bu durumun gerçekleştirilebilmesinde öğretmenlerin kişisel, mesleki nitelikleri ve yeterlilikleri açısından kendilerini yetiştirmeleri ve donanımlı olmalar1 gerekir. 
Öğretmen toplumda yaşam kalitesi ve davranışları ile öğrencilerin yaşam alanlarının merkezinde yer alır. Öğretmenlerin müzik dinleme alışkanlıkları ile estetik bakış açısından öğrencilerin yaşantılarında onlara örnek olarak müzik beğenilerini üst seviyelere taşıması beklenir. Bu noktada öğretmenlerin müzik tercihlerinin, müzik dinleme alıșkanlıklarının saptanmasının önemli olduğu düșünülmektedir. Okul ortamı kültürlenmenin en yoğun olduğu alan olarak düşünüldüğünde, farklı kültürlere sahip öğretmenlerin de toplumdaki görev ve sorumluluklarının yanı sıra kültürlerini aktarmada da en önemli aktörler olduğu düşünülmektedir. Kocaeli, Türkiye'nin en büyük sanayi şehirlerinden olması ve yoğun bir şekilde göç alması bakımından farklı kültürlerin yoğunlaştı̆ı bir ildir. Yapılan alan yazın taraması sonucunda öğretmen adaylarının müzik tercihleri üzerine çeşitli çalışmalar yapıldığı saptanmış ve alanda çalışan öğretmenlerin müzik tercihlerini sorgulayan çalışmalara rastlanmamıştır. Bu durum araştırmacıları, Kocaeli’de yaşayan öğretmenlerin müzik dinleme alışkanlıklarının neler olduğu konusunu sorgulamaya yönlendirmiştir.

Araştırmada Kocaeli'de görev yapan öğretmenlerin müzik dinleme alışkanlıklarının incelenmesi amaçlanmaktadır. $\mathrm{Bu}$ amaç doğrultusunda aşağıdaki sorulara cevap aranmıştır.

1. Öğretmenlerin dinlemeyi tercih ettikleri müzik türleri nelerdir?

2. Öğretmenlerin kişisel albüm arşivi bulundurma ve albüm ya da müzik listelerini dijital ortamlarda bulundurma durumları nelerdir?

3. Öğretmenlerin albüm ya da müzik listelerinin bulunduğu müzik dinlemeyi tercih ettikleri dijital platform türleri nelerdir?

4. Öğretmenlerin müzik dinlemeyi tercih ettikleri ortam türleri nelerdir?

5. Öğretmenlerin müzik dinlemek için tercih ettikleri gürlük düzeyleri nelerdir?

6. Öğretmenlerin tercih ettikleri müzik dinleme araçları ve ses verici aygit türleri nelerdir?

7. Ögrretmenlerin tercih ettikleri ve sevdikleri müziklerde etkilendikleri unsurlar nelerdir?

8. Öğretmenlerin dinledikleri müziklerin Türkçe ya da yabancı sözlü olması ile ilgili seçimleri nelerdir?

9. Öğretmenlerin müzik eğitimi alma ve çalg1 çalma durumları nelerdir?

Ülkemizin farklı şehirlerinden gelen çeşitli branşlardaki öğretmenlerin eğitimde rol model olmaları ve öğrencilerin yaşantılarında etkin olduğu düşünülmektedir. Bu bakımından, öğretmenlerin müzik dinleme yaklaşımlarının tespit edilmesinin, öğrencilerin gelişimleri, müziksel ve kültürel kazanımları, beğenileri üzerinde etkin olabileceği düşünülmektedir. Bu yüzden öğretmenlerin konu hakkındaki tercihlerinin, eğilimlerinin belirlenmesi önemlidir. Araştırma, toplumun müzik kültürünün belirginleşip, gelişmesinde etkin rol oynayan öğretmenlerin müziksel ve kültürel kazanımları, beğenilerini ve beklentilerini belirlemek açısından önem taşımaktadır.

Bu araştırma, 2020-2021 eğitim öğretim yllında, Kocaeli ilinde görev yapan farklı branşlardaki 421 öğretmen ile sınırlandırılmıştır. Araştırmada, örneklem evreni temsil edecek biçimde oluşturulmuştur. Kocaeli ilinde yer alan tüm ilçelerde görev yapan öğretmenlerin uygulanan ankete içten ve samimi cevap verdikleri varsayılmıştır.

\section{Yöntem}

Öğretmenlerin müzik dinleme alıskanlıklarını belirlemek amacıyla yapılan bu araştırmada nicel yaklaşımlara dayalı betimsel tarama yöntemi kullanılmıştır. Betimsel tarama verilen durumun ayrıntılı bir şekilde tanımlanmasıdır. "Tarama modelleri, geçmişte ya da halen var olan bir durumu var olduğu şekliyle betimlemeyi amaçlayan araştırma yaklaşımlarıdır. Araştırmaya konu olan olay, birey ya da nesne, kendi koşulları içinde ve olduğu gibi tanımlanmaya çalışılır. Onları, herhangi bir şekilde değiştirme, etkileme çabası gösterilmez" (Karasar, 2013, s.77).

\section{Evren - Örneklem}

$\mathrm{Bu}$ araştırmanın evrenini Kocaeli'de görev yapan öğretmenler oluşturmaktadır. Örneklemi ise Kocaeli’de farklı branşlarda ve farklı eğitim düzeylerinde görev yapan 421 öğretmenden oluşmaktadır. Araştırmaya katılan öğretmenlerin demografik özelliklerine göre dağllımları Tablo 1'de açıklanmıştır. 
Tablo 1. Ögretmenlerin Demografik Özelliklerine Göre Dağzllamları

\begin{tabular}{|c|c|c|c|c|c|c|c|}
\hline \multirow{2}{*}{\multicolumn{3}{|c|}{ Değişkenler }} & \multirow{3}{*}{$\frac{\text { Alt gruplar }}{20-25 \text { yaş }}$} & \multirow{3}{*}{$\frac{f}{15}$} & \multirow{4}{*}{$\frac{\%}{3.6}$} & \multicolumn{2}{|c|}{ Toplam } \\
\hline & & & & & & \multirow[t]{2}{*}{$f$} & \multirow{6}{*}{100.0} \\
\hline \multirow{5}{*}{\multicolumn{3}{|c|}{ Yaş }} & & & & & \\
\hline & & & $26-30$ yaş & 53 & & \multirow{4}{*}{421} & \\
\hline & & & $31-40$ yaş & 221 & 52.5 & & \\
\hline & & & $41-50$ yaş & 107 & 25.4 & & \\
\hline & & & 51 yaş ve üstü & 25 & 5.9 & & \\
\hline \multirow{3}{*}{\multicolumn{3}{|c|}{ Eğitim Durumu }} & Lisans & 348 & 82.6 & \multirow{3}{*}{421} & \multirow{3}{*}{100.0} \\
\hline & & & Yüksek lisans & 72 & 17.1 & & \\
\hline & & & Doktora & 1 & 0.3 & & \\
\hline \multirow{3}{*}{\multicolumn{3}{|c|}{ Kadro Durumu }} & Öğretmen & 369 & 87.6 & \multirow{3}{*}{421} & \multirow{3}{*}{100.0} \\
\hline & & & Müdür yardımcısı & 32 & 7.6 & & \\
\hline & & & Müdür & 20 & 4.8 & & \\
\hline \multirow{5}{*}{\multicolumn{3}{|c|}{ Hizmet Süresi }} & $1-5 \mathrm{yll}$ & 49 & 11.6 & \multirow{5}{*}{421} & \multirow{5}{*}{100.0} \\
\hline & & & $6-10 \mathrm{y} 1 \mathrm{l}$ & 114 & 27.1 & & \\
\hline & & & $11-15$ yll & 122 & 29.0 & & \\
\hline & & & $16-20 \mathrm{y} 1 \mathrm{l}$ & 70 & 16.6 & & \\
\hline & & & $21 \mathrm{yll} \mathrm{ve} \mathrm{üstü}$ & 66 & 15.7 & & \\
\hline \multirow{7}{*}{\multicolumn{2}{|c|}{ Sayısal Alan }} & & Matematik & 28 & 6.7 & \multirow{7}{*}{63} & \multirow{7}{*}{15.0} \\
\hline & & & Fen Bilimleri & 19 & 4.5 & & \\
\hline & & & Fizik & 6 & 1.4 & & \\
\hline & & & Kimya & 3 & 0.7 & & \\
\hline & & & Elektrik ve Elektronik & 3 & 0.7 & & \\
\hline & & & İlköğretim Matematik & 2 & 0.5 & & \\
\hline & & & Makine & 2 & 0.5 & & \\
\hline & & & Türkçe & 28 & 6.7 & & \\
\hline & & & Din Kültürü ve Ahlak Bilgisi & 24 & 5.7 & & \\
\hline & & & Sosyal Bilgiler & 22 & 5.2 & & \\
\hline & Sözel Alan & & Özel eğitim & 15 & 3.6 & 106 & 25.2 \\
\hline & & & Türk Dili ve Edebiyatı & 11 & 2.6 & & \\
\hline & & & Tarih & 5 & 1.2 & & \\
\hline & & & Coğrafya & 1 & 0.2 & & \\
\hline Alan & & Branş & Sınıf Öğretmeni & 76 & 18.1 & & \\
\hline & & & Müzik & 46 & 10.9 & & \\
\hline & & & Okul Öncesi & 20 & 4.8 & & \\
\hline & & & Beden Eğitimi & 19 & 4.5 & & \\
\hline & & & Görsel Sanatlar & 19 & 4.5 & & \\
\hline & Eşit Ağırlık Alanı & & Psikolojik Danışmanlık ve Rehberlik & 9 & 2.1 & 203 & 48.2 \\
\hline & & & Teknoloji ve Tasarım & 5 & 1.2 & & \\
\hline & & & Bilişim Teknolojileri & 5 & 1.2 & & \\
\hline & & & Giyim Üretim Teknolojisi & 2 & 0.5 & & \\
\hline & & & Felsefe & 1 & 0.2 & & \\
\hline & & & El sanatları & 1 & 0.2 & & \\
\hline & & & İngilizce & 39 & 9.3 & & \\
\hline & & & Almanca & 7 & 1.7 & 49 & 11.6 \\
\hline & Yabanc1 Dil Alanı & & Fransizca & 3 & 0.7 & & \\
\hline & & & Toplam & 421 & 100.0 & 421 & 100.0 \\
\hline
\end{tabular}

Tablo 1 incelendiğinde yaş düzeyleri bakımından 31- 40 yaş arası $\% 52.5$ ve $41-50$ yaş arası $\% 25.4$ grupların en yoğun gruplar olduğu, 20- 25 yaş aras1 \%3.6 ve 51 yaş ve üstü $\% 5.9$ gruplarının en az yoğunluğa sahip gruplar olduğu görülmektedir. Eğitim durumları bakımından, öğretmenlerin \%82.6's1 lisans mezunu, \%17.1'i yüksek lisans mezunu ve \%0.3'ünün doktora mezunu oldukları görülmektedir. Kadro durumları bakımından, \%87.6'sı öğretmen, \%7.6's1 müdür yardımcıs1, \%4.8'inin müdür statüsünde çalıştığı görülmektedir. Hizmet süreleri bakımından, $11-15$ y1l arası $\% 29.0$ ve $6-10$ yıl arası $\% 27.1$ grupların en yoğun gruplar olduğu, 16- 20 yll arası \%16.6, 21 y1l ve üstü \%15.7, 1-5 yıl aras1 \%11.6 gruplarının en az yoğunluğa sahip gruplar olduğu görülmektedir. Alan bakımından, öğretmenlerin \%48.2 ile en fazla eşit ağırlık alanlarında, \%11.6 ile en az yabancı dil alanlarında yoğunlaştıkları görülmektedir. Branşlar bakımından, sırasıyla \%18.1 ile sınıf öğretmeni, \%10.9 ile müzik öğretmeni branşlarının en yoğun olduğu, $\% 0.2$ ile coğrafya, el sanatları ve felsefe öğretmenlerinin en az yoğunlukta olduğu görülmektedir. 


\section{Veri Toplanması ve Çözümlenmesi}

Veri toplama aracı olarak anket tekniği kullanılmıştır. Bu doğrultuda araştırmacılar tarafından hazırlanan ve öğretmenlerin müzik dinleme alışkanlıklarını saptamak için 12 sorudan oluşan "öğretmenlerin müzik dinleme alışkanlıkları" anketi uygulanmıştır. Anket soruları hazırlanırken müzik alanından, eğitim bilimleri alanından olmak üzere toplam 2 uzmandan görüş alınmıştır. Anket sorularının tamamı kapalı uçlu soru olarak tasarlanmış olup, yalnızca 3. ve 12. sorular verilen cevaba göre katılimcıları ek olarak tasarlanan açı uçlu soruya yönlendirmektedir. Anket soruları çevrimiçi anket siteleri yardımıyla hazırlanıp, öğretmenlere gönderilerek verilere ulaşılmıştır. Elde edilen verilerin analizinde tanımlayıcı istatistik tekniklerden frekans ve yüzde dağılımlarından yararlanılmıştır.

\section{Bulgular}

Araştırmanın bulgular kısmında öğretmenlerin müzik dinleme alışkanlıklarını belirlemek için yapılan araştırma bulguları aşağıdaki tablolarda verilmiştir.

Tablo 2. Arasțtrmaya Katılan Ögrretmenlerin Dinlemeyi Tercih Ettikleri Mü̃ik Türlerine Göre Dağ̀llamı (n=421)

\begin{tabular}{lccc}
\hline & Müzik Türleri & $\boldsymbol{f}$ & $\boldsymbol{\%}$ \\
\hline Pop Müzik & & 138 & 32.8 \\
Türk Halk Müziği & & 117 & 27.8 \\
Rock Müzik ve Türleri & & 56 & 13.3 \\
Türk Müziği & & 42 & 10.0 \\
Klasik Müzik & & 20 & 4.8 \\
Caz Müzik & & 12 & 2.9 \\
Arabesk Müzik & & 7 & 1.7 \\
\hline Toplam & Özel bir tercihi olmayanlar & 392 & 93.1 \\
\hline & Etnik Müzik & 11 & 2.6 \\
Diğer Müzik Türleri & Hip- Hop/ Rap Müzik & 7 & 1.7 \\
& Tasavvuf Müziği & 6 & 1.4 \\
& Enstrümantal Müzik & 3 & 0.7 \\
\hline
\end{tabular}

Öğretmenlerin “dinledikleri müzik türleri” Tablo 2'de verilmiştir. Bu verilere göre en çok tercih edilen müzik türünün Pop Müzik \%32.8, en az tercih edilen müzik türünün Arabesk Müzik \%1.7 olduğu görülmektedir. Öğretmenlerin en çok dinlenen müzikler haricinde "dinledikleri müzik türleri" arasında diğer seçeneği ile özel tercihi olmayan \%2.6, Etnik müzik \%1.7, Hip-Hop/Rap müzik \%1.4, Tasavvuf müziği $\% 0.7$, Enstrümantal müzik $\% 0.5$ oranla tercih ettikleri görülmektedir.

Tablo 3. Araştırmaya Katılan Öğretmenlerin Kişisel Albüm Arşivi Bulundurma Durumuna Göre Dağılımı (n=421)

\begin{tabular}{lcc}
\hline \multicolumn{1}{c}{ Kisisel Albüm } & $\boldsymbol{f}$ & $\boldsymbol{\%}$ \\
\hline Kişisel albümü mevcut olan & 172 & 40.9 \\
Kişisel albümü mevcut olmayan & 249 & 59.1 \\
\hline
\end{tabular}

Tablo 3 incelendiğinde, örneklem grubunun "kişisel albüm arşivleri” durumuna göre, kişisel albümü mevcut olmayan \%59.1 ve kişisel albümü mevcut olan \%40.9 öğretmenden oluştuğu görülmektedir.

Tablo 4. Öğretmenlerin Dijital Ortamlarda Dinlemek Üzere Oluşturduklar Albüm ya da Mü̈ilk Listeleri Durumuna Göre Dağzllmu (n=421)

\begin{tabular}{lcc}
\hline \multicolumn{1}{c}{ Dijital Ortamlarda Albüm - Müzik Listeleri } & $\boldsymbol{f}$ & $\boldsymbol{\%}$ \\
\hline Albüm ya da müzik listeleri mevcut olan & 243 & 57.9 \\
Albüm ya da müzik listeleri mevcut olmayan & 178 & 42.1 \\
\hline
\end{tabular}

Öğretmenlerin “dijital ortamlarda oluşturdukları albüm ve müzik listeleri” Tablo 4’te verilmiştir. Bu verilere göre, dijital ortamlarda kişisel albüm ya da müzik listeleri mevcut olan \%57.9, kişisel albüm ya da müzik listeleri mevcut olmayan \%42.1 öğretmenden oluştuğu görülmektedir. 
GÖKÇEN, CAN ve BAĞCI

Kocaeli İlinde Görev Yapan Öğretmenlerin Müzik Dinleme Alışkanlıklarının İncelenmesi

Tablo 5. Öğretmenlerin Albüm ya da Müzik Listelerinin Bulunduğu Dijital Platform Türlerine Göre Dağ̊llmı (n=421)

\begin{tabular}{llcc}
\hline \multicolumn{2}{c}{ Dijital Platform } & $\boldsymbol{f}$ & $\boldsymbol{\%}$ \\
\hline Dijital platform tercih etmeyenler & & 143 & 34.0 \\
\hline & Youtube & 150 & 35.6 \\
& Spotify & 70 & 16.6 \\
& Fizy & 27 & 6.4 \\
& Kişisel harici bellek & 19 & 4.5 \\
Dijital platform tercih edenler & One & 3 & 0.7 \\
& Tubidy & 2 & 0.5 \\
& Muud & 2 & 0.5 \\
& Itunes & 2 & 0.5 \\
& SSound & 1 & 0.2 \\
& Deezer & 1 & 0.2 \\
\hline
\end{tabular}

Öğretmenlerin “albüm ve müzik listelerinin bulunduğu dijital platformlar” Tablo 5’te verilmiştir. Bu verilere göre dijital platform tercih eden öğretmenlerin \%66.0 kişiden oluştuğu, dijital platform tercih etmeyen öğretmenlerin ise \%34.0 kişiden oluştuğu görülmektedir.

Tablo 6. Öğretmenlerin Müzik Dinlemeyi Tercih Ettikleri Ortam Türlerine Göre Dağılımı (n=421)

\begin{tabular}{lccc}
\hline & Müzik dinleme ortami & $\boldsymbol{f}$ & \% \\
\hline Herhangi bir ortam & 209 & 49.6 \\
Tek başıma & 202 & 48.0 \\
Arkadaşlarımla birlikte & 10 & 2.4 \\
\hline
\end{tabular}

Tablo 6 incelendiğinde, öğretmenlerin “müzik dinlemeyi tercih ettikleri ortamlar” durumuna göre, tercih konusunda herhangi bir ortam yanıtını veren \%49.6, tek başına dinlemeyi tercih eden \%48.0, arkadaşlarıyla birlikte dinlemeyi tercih eden \%2.4 öğretmenden oluştuğu görülmektedir.

Tablo 7. Ögrretmenlerin Müzik Dinlerken Tercih Ettikleri Gürlüke Düzeylerine Göre Dağılımı (n=421)

\begin{tabular}{lccc}
\hline & Müzik dinleme düzeyi & $\boldsymbol{f}$ & $\boldsymbol{\%}$ \\
\hline Orta düzey & 292 & 69.4 \\
Yüksek sesle & 108 & 25.7 \\
Kisk sesle & 21 & 5.0 \\
\hline
\end{tabular}

Tablo 7 incelendiğinde, öğretmenlerin “müzik dinlemeyi tercih ettikleri gürlük düzeyleri” durumuna göre, orta düzeyde müzik dinleyen $\% 69.4$, yüksek sesle müzik dinleyen $\% 25.7$ ve k1s1k sesle müzik dinleyen \%5.0 öğretmenden oluştuğu görülmektedir.

Tablo 8. Öğretmenlerin Müzik Dinledikleri Araç Türlerine Göre Dağllım (n=421)

\begin{tabular}{lccc}
\hline & Müzik dinleme araçlart & $\boldsymbol{f}$ & $\boldsymbol{\%}$ \\
\hline Telefon & 318 & 50.7 \\
Bilgisayar/Tablet & 145 & 23.1 \\
Televizyon & 62 & 9.9 \\
Müzik seti & 51 & 8.1 \\
Kişisel müzik çalar & 51 & 8.1 \\
\hline
\end{tabular}

Tablo 8 incelendiğinde, öğretmenlerin "müzik dinledikleri araçlar” durumuna göre, telefondan müzik dinleyen $\% 50.7$, bilgisayar/tabletten müzik dinleyen \%23.1, televizyondan müzik dinleyen \%9.9, müzik setinden müzik dinleyen \%8.1 ve kişisel müzik çalardan müzik dinleyen \%8.1 öğretmenden oluştuğu görülmektedir.

Tablo 9. Öğretmenlerin Müzik Dinlemeyi Tercib Ettikleri Ses Verici Aygıt Türlerine Göre Dă̆ılımı (n=421)

\begin{tabular}{|c|c|c|}
\hline Müzik dinlemeyi tercih ettikleri aygtt & $f$ & $\%$ \\
\hline Hoparlör & 260 & 52.4 \\
\hline Kulaklık & 163 & 32.9 \\
\hline $5+1$ Ses sistemi & 73 & 14.7 \\
\hline
\end{tabular}

Tablo 9 incelendiğinde, öğretmenlerin “müzik dinlemeyi tercih ettikleri ses verici ayg1tlar” durumuna göre, hoparlör tercih eden \%52.4, kulaklik tercih eden \%32.9, 5+1 ses sistemi tercih eden \%14.7 öğretmenden oluştuğu görülmektedir. 
Tablo 10. Öğretmenlerin Tercih Ettikleri Müzįlelerde Etkilendikleri Unsurlara Göre Dağılımı (n=421)

\begin{tabular}{lcc}
\hline Tercih edilen müziklerde etkilenilen unsurlar & $\boldsymbol{f}$ & $\boldsymbol{\%}$ \\
\hline Müzikal faktörlere göre (biçim, armoni, ritim, artikülasyon vb.) & 199 & 47.3 \\
Geçmişten bugüne kadar elde ettiğim deneyim ve birikime göre & 153 & 36.3 \\
Şarkı sözlerine göre & 55 & 13.1 \\
Aile ve Çevremin yönlendirmesi & 2 & 0.5 \\
\hline Ruh haline göre & 4 & 1.0 \\
Dini hassasiyetlerime göre & 1 & 0.2 \\
Verdiği keyif & 1 & 0.2 \\
Hissettirdiŏi duygular & 1 & 0.2 \\
Ritim ve sözlerin uyumu & 1 & 0.2 \\
Duygularıma hitap edenleri & 1 & 0.2 \\
Hem şairanelik, hem müzikalite & 1 & 0.2 \\
Bazen müzikal alt yapi, bazen de sözlerine dikkat ederim & 1 & 0.2 \\
Orijinal yorum & 1 & 0.2 \\
\hline Toplam & 12 & 2.8 \\
\hline
\end{tabular}

Öğretmenlerin "tercih ettikleri müziklerde etkilendikleri unsurlar" Tablo 10'da verilmiştir. En fazla etkilendikleri unsurlar müzikal faktörlere göre (biçim, armoni, ritim, artikülasyon vb.) \%47.3, en az etkilendikleri unsurlar aile ve çevremin yönlendirmesine göre $\% 0.5$ olduğu görülmektedir. Tercih edilen müziklerdeki müzikal unsurlar arasında diğer seçeneği öğretmenlerin "tercih ettikleri müziklerde etkilendikleri unsurlar" arasında ruh haline göre $\% 1.0$, dini hassasiyetlere göre $\% 0.2$, verdiği keyfe göre $\% 0.2$, hissettirdiği duygulara göre $\% 0.2$, ritim ve sözlerin uyumuna göre $\% 0.2$, duygularıma hitap edenlere göre $\% 0.2$, hem şairanelik. hem de müzikaliteye göre $\% 0.2$, bazen müzikal alt yap1, bazen de sözlerine dikkat etme durumuna göre $\% 0.2$, orijinal yoruma göre $\% 0.2$ olmak üzere toplamda $\% 2.8$ tercihten oluştuğu görülmektedir.

Tablo 11. Öğretmenlerin Sevdikleri Müziklerde Etkilendikleri Unsurlara Göre Dağglmm (n=421)

\begin{tabular}{|c|c|c|}
\hline Sevilen müzik türlerinde etkilenilen unsurlar & $f$ & $\%$ \\
\hline Hepsi & 186 & 44.2 \\
\hline Melodi & 55 & 13.1 \\
\hline Şarkı sözleri & 42 & 10.0 \\
\hline Ritim ve Tempo & 39 & 9.3 \\
\hline Müziğin Dönemsel Özellikleri (80’ler, 90’lar, romantik dönem, çağdaş dönem vb.) & 39 & 9.3 \\
\hline Müzik parcasının tınısı, ses rengi ve tınısal özelikleri ile ilgili teknolojik olanakları & 36 & 8.6 \\
\hline Calgrlima (koncerto, sonat, senfoni vb.) & 11 & 2.6 \\
\hline Armoni & 8 & 1.9 \\
\hline Biçim. Stil & 3 & 0.7 \\
\hline Müziğin hikâyesi & 1 & 0.2 \\
\hline Bazılarının melodisi, bazılarının sözlerini, bazılarında ise her ikisi de & 1 & 0.2 \\
\hline
\end{tabular}

Öğretmenlerin "sevdikleri müziklerde etkilendikleri unsurlar" Tablo 11'de verilmiştir. Bu verilere göre en fazla \%44.2 ile hepsi ve \%13.1 ile melodi seçenekleri, en az ise \%0.7 ile biçim, stil; diğer başlı̆̆ altında ise \%0.2 ile müziğin hikâyesi ve bazılarının melodisi, bazılarının sözlerini, bazılarında ise her ikisi de seçeneklerini tercih ettikleri görülmektedir.

Tablo 12. Ögretmenlerin Dinledikleri Müziklerin Türkse ya da Yabancı Sǫ̈lü Olması Seçimlerine Göre Dăğllmı $(n=421)$

\begin{tabular}{lcc}
\hline \multicolumn{1}{c}{ Müziklerin Türkçe ya da yabancı sözlü olması } & $\boldsymbol{f}$ & $\boldsymbol{\%}$ \\
\hline Müziklerin Türkçe ya da yabanc1 sözlü olması önemli değil & 164 & 39.0 \\
Müziklerin Türkçe ya da yabanc1 sözlü olması kismen önemli & 145 & 34.4 \\
Müziklerin Türkçe ya da yabanc1 sözlü olması önemli & 112 & 26.6 \\
\hline
\end{tabular}

Örneklem grubunu oluşturan öğretmenlerin "dinledikleri müziklerin Türkçe ya da Yabancı sözlü olması" Tablo 12'de verilmiştir. Bu verilere göre, müziklerin Türkçe ya da yabancı sözlü olması önemli değil \%39.0, müziklerin Türkçe ya da yabancı sözlü olması kısmen önemli \%34.4, müziklerin Türkçe ya da yabanc1 sözlü olması önemli \%26.6 öğretmenden oluştuğu görülmektedir.

Tablo 13. Ögrretmenlerin Müzik Eğitimi Alma Durumlarna Göre Dağglamı $(n=421)$

\begin{tabular}{lccc}
\hline & Müzik ĕ̈itimi durumu & $\boldsymbol{f}$ & \% \\
\hline Müzik eğitimi alan & & 47 & 11.2 \\
Müzik eğitimi almayan & & 374 & 88.8 \\
\hline
\end{tabular}


Öğretmenlerin “müzik eğitimi alma durumları” Tablo 13’te verilmiştir. Bu verilere göre, müzik eğitimi almayan \%88.8, müzik eğitimi alan \%11.2 öğretmenden oluştuğu görülmektedir.

Tablo 14. Araștırmaya Katılan Öğretmenlerin Calgı Calma Durumlarına Göre Dağılımı (n=421)

\begin{tabular}{lccc}
\hline & Çalg1 çalma durumları & $\boldsymbol{f}$ & \% \\
\hline Çalg1 çalan & & 126 & 29.9 \\
Çalgı çalamayan & 295 & 70.1 \\
\hline
\end{tabular}

Örneklem grubunu oluşturan öğretmenlerin “müzik çalg1 çalma durumları” Tablo 14'te verilmiştir. Bu verilere göre çalg1 çalmayan \%70.1, çalg1 çalan \%29.9 öğretmenden oluştuğu görülmektedir.

Tablo 15. Çalgı Çalan Öğretmenlerin Çalgı Türlerine Göre Dağılımı

\begin{tabular}{|c|c|c|c|c|}
\hline & Çalgılar & & $f$ & $\%$ \\
\hline \multirow{19}{*}{ Batı Müziği Çalgıları } & \multirow{5}{*}{ Tusşlu Çalgılar } & Piyano & 22 & 14.4 \\
\hline & & Org & 5 & 3.3 \\
\hline & & Akordeon & 2 & 1.3 \\
\hline & & Kalimba & 1 & 0.7 \\
\hline & & Toplam & 30 & 19.6 \\
\hline & \multirow{5}{*}{ Telli Çalg1lar } & Gitar & 19 & 12.4 \\
\hline & & Ukulele & 2 & 1.3 \\
\hline & & Mandolin & 2 & 1.3 \\
\hline & & Bas Gitar & 1 & 0.7 \\
\hline & & Toplam & 24 & 15.7 \\
\hline & \multirow{4}{*}{ Üflemeli Çalgılar } & Blok Flüt & 19 & 12.4 \\
\hline & & Flüt & 4 & 2.6 \\
\hline & & Saksafon & 1 & 0.7 \\
\hline & & Toplam & 24 & 15.7 \\
\hline & \multirow{2}{*}{ Yaylı Çalgılar } & Keman & 17 & 11.1 \\
\hline & & Toplam & 17 & 11.1 \\
\hline & \multirow{3}{*}{ Vurmalı Çalgılar } & Bateri & 2 & 1.3 \\
\hline & & Perküsyon & 1 & 0.7 \\
\hline & & Toplam & 3 & 2.0 \\
\hline Toplam & & & 98 & 64.1 \\
\hline \multirow{12}{*}{ Türk Müziği Çalgılar } & \multirow{4}{*}{ Telli Çalgılar } & Bağlama & 36 & 23.5 \\
\hline & & Kanun & 4 & 2.6 \\
\hline & & Tambur & 2 & 1.3 \\
\hline & & Toplam & 42 & 27.5 \\
\hline & Üflemeli Çalg1lar & Ney & 8 & 5.2 \\
\hline & & Toplam & 8 & 5.2 \\
\hline & \multirow{4}{*}{ Vurmalı Çalgılar } & Bendir & 2 & 1.3 \\
\hline & & Darbuka & 1 & 0.7 \\
\hline & & Erbane & 1 & 0.7 \\
\hline & & Toplam & 4 & 2.6 \\
\hline & \multirow[t]{2}{*}{ Yaylı Çalgılar } & Klasik Kemençe & 1 & 0.7 \\
\hline & & Toplam & 1 & 0.7 \\
\hline Toplam & & & 55 & 35.9 \\
\hline Toplam & & & 153 & 100.0 \\
\hline
\end{tabular}

Öğretmenlerin “müzik çalg1 çalma durumları” Tablo 15’te verilmiştir. Bu verilere göre, öğretmenler batı müziği çalgılarında tuşlu çalgılar $\% 19.6$, telli çalg1lar $\% 15.7$, üflemeli çalgılar \%15.7, yaylı çalgılar $\% 11.1$, vurmalı çalgılar \%2.0 olmak üzere toplamda \%64.1; Türk müziği çalgılarında telli çalg1lar \%27.5, üflemeli çalgılar $\% 5.2$, vurmalı çalg1lar \%2.6, yaylı çalg1lar $\% 0.7$ olmak üzere toplamda $\% 35.9$ çalg1 çaldıkları görülmektedir.

\section{Sonuç, Tartışma ve Öneriler}

\section{Sonuç ve Tartışma}

Araştırmanın “Öğretmenlerin dinlemeyi tercih ettikleri müzik türleri nelerdir?” 1. alt amacına yönelik elde edilen bulgular neticesinde;

Öğretmenlerin en çok dinlediği müzik türleri sorusuna bakıldı̆̆ında, \%32.8'inin ilk sırada Pop müzik dinlediği 2.sırada \%27.8' inin 'Türk Halk müziği dinlediği tespit edilmiştir. Benzer sonuçlara farklı çalışmalarda da ulaşılmıştır (Atasoy, 2019, s. 227; Özdemir ve Can, 2019, s. 377; Dobrota ve Ercegovac, 2017, s. 46; Taş, 2011, s. 100; Çevik, Akın, Onuk ve Yalçınkaya, 2003, s. 8; Gökbudak ve Gökbudak, 2003, 
s. 40). Farklı araştırmalarda da Türk Halk müziği ilk sırada, pop müziği 3.sırada tercih edilmektedir (Uslu ve Göher, 2011; Şahin, 2019). Pop müziğinin yaygınlı̆̆ı, pop müzik ile ilgili yayınların fazla olması ve popüler kültürün etkisi ile en fazla pop müzik dinledikleri sonucuna ulaşılabilir. Farklı araştırmalarda elde edilen sonuçlara göre öğretmenler müzik türleri arasında en çok pop müziği tercih etmektedir. (Woody ve Burns, 2001, s. 62; Hui, 2001, s. 126; De Vries, 2010, s. 15; Yağışan, 2013, s. 103; Ulutürk, 2008, s. 50).

Türk Halk müziğinin pop müzikten sonra tercih edilmesinin nedeni ülkemizin öz müziği olması, kültürümüzü, kültür çeşitliliğini yansıtması ve Türk Halk müziği ile ilgili çalş̧aların takip edildiği sonucuna varılabileceği ile ifade edilebilir. Dinlenilen müzik türleri arasında öğretmenlerin \%1.7'sinin en az Arabesk müzik dinledikleri görülmektedir. Son ylllarda özellikle alt sosyo-ekonomik düzeyde yer alan dinleyiciler arasında daha fazla arabesk müzik dinlenildiği (Yıldırım, s.59), fakat teknolojik gelişim, dijital platformlarda mevcut popüler türlerin yaygınlğg1 sonucu, arabesk müziği dinleme oranının genel olarak azaldığ1 görülmüştür (Dönmez ve İmik, 2020, s. 138). İmik (2007) ve Doğan (2008) tarafindan yapılan araştırmalarda da bireylerin en çok arabesk müzik dinlediği, bu durumun toplum içerisinde sosyal ve ekonomik sebeplerden kaynaklandığ1 görülmektedir. Arabesk müzik dinleyici kitlesinin genel olarak gelir ve eğitim seviyesi düşük bireylerden meydana geldiği, sosyo-ekonomik düzeyi düşük olanların ağırlıkta olduğu, ayrıca eğitim seviyesinin yükselmesi ile arabesk müzik dinleme oranının azaldığı sonucuna ulaşılmışır. Bu araştırmada da arabesk müziğin öğretmenler tarafindan daha az tercih edilmesi sonucunu destekler niteliktedir.

Türk Dil Kurumu Sözlüğü, arabesk kavramını "bireyin kendi düşünce ve davranışlarını dıştaki direnmelere karşı, zorla karşısındakine benimsetme çabası" olarak tanımlamaktadır (TDK, 2020). Arabesk müziği, Pop Müzik ve Türk Halk Müziğinden ayıran özelliklerden bir tanesi daha çok ruhsal gerginliklerin dışa vurulması ile saldırganlık oluşması durumu ile ilgili temaları içermesidir (Güngör,1993, s. 24). Arabesk müziğinin söz ve müzikal içeriğinde bu yansımalarını taşıması bakımından, öğretmenlerin bu durumdan uzak olduğu düşünülebilir. Tüm bu sonuçlar doğrultusunda öğretmenler müzik tercihinde bulunurken, müzik dinlemeyi tercih ettikleri ortamlarla birlikte, içinde bulundukları ruh hali (Woody ve Burns, 2001, s. 66), sosyal çevreden ve hali hazırdaki ekonomik durumlarından etkilendikleri sonucuna ulaşılabilir. Ercan (2014), tarafından yapılan araştırmada da lisans düzeyinde klasik batı müziği eğitimi verilen devlet konservatuvarı müzik bölümü öğrencilerinin Türk Halk Müziği ve Arabesk Müzik türüne açık oldukları, fakat bu türleri tercih etmedikleri sonucuna ulaşılmıştır.

Araştırmanın "Öğretmenlerin kişisel albüm arşivi bulundurma ve albüm ya da müzik listelerini dijital ortamlarda bulundurma durumları nelerdir?” 2. alt amacına yönelik elde edilen bulgular neticesinde;

Öğretmenlerin kişisel fiziki albüm arşivi bulundurma durumu incelendiğinde; elde edilen verilere göre \%59.1'nin hayır yanıtı ile çoğunluğun kişisel albüm arşivlerinin olmadığı tespit edilmiştir. Araştırmanın bir başka sorusu olan dijital ortamlarda oluşturulan albüm ya da müzik listeleri durumu incelendiğinde; \%57.9 evet yanıtı ile öğretmenlerin daha çok dijital ortamlarda müzik arşivi oluşturdukları sonucuna ulaşılmıştır. Elde edilen sonuçlara göre her iki durumun tersi yönde yüksek çıkmıştır. Bu sonuçlara göre öğretmenlerin her durumda müzik dinlemeyi tercih ettiği, fakat daha çok dijital platformlara yöneldiği sonucunu göstermektedir. Albüm arşivi konusunda teknolojik imkânların gelişmesi, yaygınlaşması, internet ortamında kolay ve ulaşılır olması bakımından; müzik arşivlemede dijital ortamların tercih edildiği sonucuna ulaşılabilir. Dijital ortamların büyük arşivleri kolay ulaşılabilir kılması, kullanılan aygıtlarda, fiziksel ortamlarda az yer kaplaması, düşük maliyetlerle ulaşılabilir olması cazip yönleri olarak düşünülebilir. Oğuz (2016) tarafindan gençlerin dijital müzik tüketim alışanlıklarını tespit etmeye yönelik yapılan çalışmada, müzik dinlemek için \%46'llk veri ile dijital müzik ortamları, müzik tüketim tercihi olarak da \%98'lik veri ile dijital tüketimi tercih etmektedir. Elde edilen sonuçlar açısından dijital kayıt teknolojisine gençlerin adapte oldukları ve mobilize yaşam biçimini benimsemiş olmaları gibi bu araştırma verileri ile benzer sonuçlara ulaşılmıştır.

Araştırmanın "Öğretmenlerin albüm ya da müzik listelerinin bulunduğu müzik dinlemeyi tercih ettikleri dijital platform türleri nelerdir?” 3. alt amacına yönelik elde edilen bulgular neticesinde;

Öğretmenlerin albüm ve müzik listeleri bulundurduğu dijital platform türleri incelendiğinde, $\% 66.0$ öğretmenlerin gelişen teknoloji ile müzik dinlemede dijital platformları tercih ettikleri ve aktif olarak bu ortamları kullandıkları anlaşılmaktadır. Oğuz (2016) tarafindan yapılan araştırmada da gençlerin müzik dinlemek için dijital platformları tercih ettiği sonucuna ulaşılmıştır. Dinlemek istedikleri müziklere ulaşılabilirlik açısından internet ortamını tercih ettikleri görülmektedir. Dijital platformlardan \%35.6 veri ile 
ilk sırada youtube, \%16.6 veri ile 2. sirada spotify, \%6.4 veri ile 3. Sirayı fizzy izlemektedir. (Digital Age, 2018). Bu platformlar dışında en az tercih edilen dijital platformlar one, tubidy, muud, itunes, isound, deezer, myt müzik platformlarıdır. Bu platformların daha az tercih edilmesinin nedeni, yeni oluşan platformlar olmaları ve platformlarla ilgili yayınların henüz az olması olarak düşünülebilir. Youtube platformunun albüm ve müzik listelerinin bulunduğu dijital platformlar arasında en eski platform olması, yeni çıkan albümlerin reklamında bu platformun sık kullanılması, kullanıcılara sunduğu kullanım ve paylaşım kolaylığı (De Vries, 2010), içerik zenginliği bakımından ilk sırada tercih edildiği sonucuna ulaşılabilir.

Araştırmanın "Öğretmenlerin müzik dinlemeyi tercih ettikleri ortam türleri nelerdir?" 4. alt amacına yönelik elde edilen bulgular neticesinde;

Öğretmenlerin müzik dinlemeyi tercih ettikleri ortam türleri incelendiğinde; \%49.6's1 herhangi bir ortam, \%48.0'ının tek başına, \%2.4'ünün ise arkadaşlarıyla birlikte müzik dinlemeyi tercih ettiği tespit edilmiştir. Buna göre öğretmenlerin müzik dinleme ortamları için seçici olmadıkları sonucuna ulaşılabilir. Hui'nin (2001) yaptı̆̆1 çalışmada da öğrencilerin çoğunlukla tek başına müzik dinlemeyi tercih ettikleri tespit edilmiştir.

Araştırmanın “Öğretmenlerin müzik dinlemek için tercih ettikleri gürlük düzeyleri nelerdir?” 5. alt amacına yönelik elde edilen bulgular neticesinde;

Öğretmenlerin müzik dinlerken tercih ettikleri gürlük düzeyleri incelendiğinde; \%69.4 orta düzey, \%25.7 yüksek sesle, \%5.0 kısık sesle müzik dinlemeyi tercih etmekte olduğu sonucu görülmüştür. Öğretmenlerin yaş gruplarına bakıldığında orta yaş öğretmenlerin daha ağırllkta olduğu görülmekle beraber, en fazla orta düzeyde müzik dinleme seçeneğiyle sonuçlanması ve bu sonuçların ilişkilendirilebileceği düşünülmektedir. Araştırmaya katılan öğretmenlerin yaşı ile müzik dinleme düzeyleri arasında ulaşılan sonuçlar bakımından bir ilişki olduğu düşünülebilir. Ses düzeyi algisı dinleyicilere göre farklılık gösterse de çıkan sonuçlar dikkate alınabilecek verilerdir. Erdal (2009) ve Tanrıkulu (2011) tarafindan yapılan araştırmalarda da öğrencilerin orta düzeyde müzik dinlemeyi tercih ettikleri sonucuna ulaşılmıştır. Araştırma sonuçları literatürde yer alan bu sonuçlarla da örtüşmektedir.

Araştırmanın "Öğretmenlerin tercih ettikleri müzik dinleme araçları ve ses verici aygit türleri nelerdir?” 6. alt amacina yönelik elde edilen bulgular neticesinde;

Öğretmenlerin müzik dinledikleri araç türleri incelendiğinde; \%50.7 Telefon, \%23.1 Bilgisayar/Tablet, \%9.9 Televizyon, \%8.1 Müzik seti, \%8.1 Kişisel müzik çalar tercih edilmektedir. Ulaşılan sonuçlara göre katılımcıların müzik dinleme aracı olarak en çok cep telefonlarını tercih ettikleri görülmektedir. Yapılan çeşitli çalışmalarda da gençlerin müzik dinlemek için en çok akıllı telefon tercih ettikleri sonucuna ulaşılmıştır (Oğuz, 2016, s. 54; Digital Age, 2018; Doğan, 2020, s. 1597). Gelişen teknoloji ve akıllı telefonlara sahip olan katılımcıların sayısının fazlalı̆̆ı göz önünde tutulduğunda ulaşılan sonuç mantıklı görülmektedir. Telefon sürekli ulaşılabilir durumda bir araç durumundadır. Bu bakımdan da bir tercih nedeni olabilir. Ancak bu sonuç, katılımcıların özellikle müzik dinlemek için özel bir çabasının olmadığını sonucunun da göstergesi olabilir.

Öğretmenlerin müzik dinlemeyi tercih ettikleri aygtt türleri incelendiğinde, \%52.4 ile hoparlör, \%32.9 ile kulaklık, \%14.7 5+1 ses sistemi tercih ettikleri tespit edilmiştir. Öğretmenlerin ilk sırada hoparlör tercih etmeleri müzikten alınan verimin, müziğin anlaşılma derecesinin, müzik dinleme araçları ve kaynağının ses kalitesine bağlı olmasıdır. Müzik dinleme araçlarında gelişen teknoloji ile ses kalitesine önem vermeleri konusunda dikkatli ve hassas oldukları düşünülebilir. Kulak sağlığına önem vermeleri, işitme konusunda problem (Tanrikulu, 2011, s. 46) yaşayacakları düşüncesiyle kulaklığ1 2. sırada tercih ettikleri düşünülmektedir.

Araştırmanın "Öğretmenlerin tercih ettikleri ve sevdikleri müziklerde etkilendikleri unsurlar nelerdir?" 7. alt amacına yönelik elde edilen bulgular neticesinde;

Öğretmenlerin tercih ettikleri müziklerde etkilendikleri unsurlara göre; en çok $\% 47.3$ oran ile müzikal faktörlere göre (biçim, armoni, ritim, artikülasyon vb.) dikkat ettikleri görülmektedir. Bu durum öğretmenlerin daha çok bilinçli bir dinleme etkinliği gerçekleştirdiklerinin göstergesidir. Müzikal faktörleri, müzik alt yapısını, müziğin barındırdığı düzeni, çalg1 türlerini, yap1 olarak içeriğini algılamak ve dinlemek, entelektüel bir birikim gerektirmektedir. Geçmişten bugüne kadar elde ettiğim deneyim ve birikime göre, şark1 sözlerine göre, aile ve çevremin yönlendirmesi, diğer etkilendikleri unsurlar seçenekleri ise yaşantıları 
içerisinde deneyimleri sonucu elde ettikleri birikimler, aldıkları eğitimler, çevrenin etkileri, aile faktörü gibi sonuçlarla ilişkilendirilebilir.

Öğretmenlerin sevdikleri müzik türlerinde etkilendikleri unsurlar incelendiğinde; Melodi, şarkı sözleri, ritim ve tempo, müziğin dönemsel özellikleri (80’ler, 90’lar, romantik dönem, çağdaş dönem vb.), müzik parçasının tınısı, ses rengi ve tınısal özelikleri ile ilgili teknolojik olanakları, çalgılama (konçerto, sonat, senfoni vb.), armoni, biçim, stil gibi \%44.2 veri ile hepsi seçeneğini tercih ettikleri görülmektedir. Benzer sonuçlara farklı çalışmalarda da ulaşılmıştır (Atasoy, 2019, s. 228). Etkilendikleri unsurlara bakıldığında gelişen teknoloji ile sevdikleri müziklerin içeriklerine detaylı bir şekilde ulaşabildiklerine, analiz yapabildiklerine, seçimleri konusunda çıkarımlar yapabildikleri sonucuna ulaşılabilir.

Araştırmanın "Öğretmenlerin dinledikleri müziklerin Türkçe ya da yabancı sözlü olması ile ilgili seçimleri nelerdir?" 8. alt amacına yönelik elde edilen bulgular neticesinde;

Öğretmenlerin dinledikleri müziklerin Türkçe ya da yabancı sözlü olması durumu incelendiğinde; Öğretmenlerin dinledikleri müziklerin Türkçe ya da yabanc1 sözlü olması konusunda \%39.0 oran ile müziklerin Türkçe ya da yabancı sözlü olması önemli değil yanıtı tercih edilmiştir. Benzer sonuçlara farklı çalışmalarda da ulaşılmıştır (Erdal, 2009). Sonuca göre sözlerin ikinci planda olduğu, önceliği müziğin aldığı ve sevdikleri müziklerdeki etkilendikleri unsurlara göre şarkı sözleri seçeneğinin çok ayırıcı bir özellik taşımadığı sonucuna varılabilir. İmik (2007) tarafindan yapılan çalışmada, katılımcıların \% 24.9' unun Türkçe sözlü, \% 2.6'sının yabancı sözlü müzik dinleyenlerin olduğu, müzik zevklerinin daha çok Türkçe sözlü türlerden oluştuğu görülmektedir.

Araştırmanın "Öğretmenlerin müzik eğitimi alma ve çalgı çalma durumları nelerdir?" 9. alt amacına yönelik elde edilen bulgular neticesinde;

Öğretmenlerin müzik eğitimi alma durumları ve çalg1 çalma durumları incelendiğinde; öğretmenlerin \%88.8 oranda müzik eğitimi almadığı, \%70.1 oranda herhangi bir çalgı çalamadıkları tespit edilmiştir. Bu sonuçların birbirine paralel yapıda olduğu görülmektedir. Müzik eğitimi almama durumu öğretmenlerin mesleklerini icraları, eğitim- ögretim sürecinde yaşadıkları yoğunluklar olabileceği ve çalg1 çalma konusunda disiplin gerektirdiği için yeterince vakit ayıramadıklarının göstergesi olabileceği düşünülmektedir.

Öğretmenlerin çalabildikleri çalg1 türlerine yönelik dağılımına incelendiğinde; Batı müziği alanında daha çok tuşlu çalgılar, telli çalgılar, üflemeli çalgılar, yaylı çalgılar ve vurmalı çalgıları; Türk Müziği alanında ise, telli çalgılar, üflemeli çalgılar, yaylı çalgılar ve vurmalı çalgıları tercih ettikleri tespit edilmiştir. Batı müziği çalgılarının \%64.1 öğretmen ile, \%35.9 Türk Müziği çalgilarından daha fazla tercih edildiği görülmektedir. $\mathrm{Bu}$ durum öğretmenlerin çaldıkları çalgıların popülerliği dinledikleri müzik türlerinde kullanılan çalgılar olabileceğini düşündürmektedir. Flowers ve Murphy (2001) yaptıkları çalışmada katılımcıların daha çok popüler çalgıları tercih ettiğini tespit etmiştir. Bu araştırmada dinlenilen müzik türlerine paralel olarak; Batı müziği çalgılarından \%14.4 öğretmenin piyano, Türk müziği çalgılarından ise \%23.5 öğretmenin bağlama çaldığı görülmektedir. Özkasnaklı ve Dalkıran (2017) yaptığı çalışmada da benzer sonuçlara ulaşılmıştır.

Araştırma sonuçları genel olarak değerlendirildiğinde, müziğin öğretmenlerin yaşamlarında önemli bir yere sahip olduğunu göstermektedir Eğitimin amaçları arasında, öğrencilerde müzik beğenisi oluşturmak, müzik dinleme tercihlerinin bilimsel bir temele dayalı olarak gelişmesini sağlamak, niçin, neyi dinlediğini bilen ilgili ve meraklı dinleyici profili oluşturmak, dinleme alışkanlığının eğitim ile olumlu yönde şekillenebileceği düşünülmektedir.

\section{Öneriler}

\section{Araştırmaya Yönelik Öneriler}

Müzik eğitimini yaşamına dâhil eden öğretmenler, müziği kendi disiplinleri ile bağdaştırarak eğitimin bir parçası olarak kullanabilir. $\mathrm{Bu}$ anlamda okul yönetimlerince öğretmenlerin müzikle uğraşması için özendirilmesi ve çalg1 çalan öğretmenlerin çeşitli etkinliklerde icralarını sergileyebilecekleri ortamlar yaratılması önerilmektedir.

Farklı branştaki öğretmenlerin müziği kendi branşlarının öğretiminde kalıcı bir öğrenme sağlamaları ve etkin kullanabilmeleri için, lisans eğitimlerine müzik eğitiminin dâhil edilerek branşları ile bağlantı kurmaları önerilmektedir. 
Müziğin yaşam boyu işlevi, eğitimdeki işlevi geniş bir açı ile ele alınmalı, müziğin diğer sanatlarla, disiplinlerle ilişkisini anlamlandırmaya yönelik çalışmalar yapılması ve branşlara uygun bir şekilde programlar düzenlenmelidir. Müzik dinleme ve anlamaya yönelik ortamların oluşturulması ve bu ortamlarda müzik dinleme alıskanlığı kazandırmak amacıyla alan uzmanlarınca rehberlik çalısmaları yapılması önerilmektedir.

Çocukların müzik dinleme alışkanlıklarını geliştirmek ve olumlu deneyimler elde etmelerini sağlamak için veliler ile iş birliği yaparak müzik eğitimi almaları, sanatsal faaliyetlere katılıp, sanatsal etkinlikleri takip etmeleri konusunda rehberlik çalışmaları yapılması önerilmektedir.

Öğretmenlerin gerek lisans eğitim süreçlerinde gerekse mezuniyet sonrası görevlerini icra etmeleri esnasında sanatsal faaliyetlere katılmaları sağlanmalıdır. Bununla birlikte öğretmenlerin öğrencilerine rehberlik edebilmeleri için müziksel etkinliklerin, konserlerin ücretlerinde öğretmen ve öğrencileri teşvik edici düzenlemeler yapılması önerilmektedir. Bu anlamda belediyeler ve çeşitli devlet kurumlarının, özel kurumların destekleyici bir rol üstlenmesinin önemli olduğu düşünülmektedir.

Öğretmenlerin eğitim öğretim faaliyetlerinde müzikle bağlantı kurabilmeleri adına, anadil öğretiminde olduğu gibi, müziği de müziğin doğal ortamı olan konserlerde, armonik alt yapısı zengin eserleri dinleyerek öğrenmelidir. Bu durum müziğin anlaşılmasını sağlayabilir, bireylerin müzik tercihlerinde seçici davranıp kendi beğenilerini oluşturmaları yönünde etken olabilir.

\section{Araştırmacılara Yönelik Öneriler}

Öğretmenlere hizmet içi eğitimlerle müzik dinleme, çalma ve söyleme konusunda rehberlik çalşmaları yapılması ve eğitim faaliyetleri düzenlenmesi önerilmektedir. Ayrıca benzer araştırmaların farklı illerde de yürütülmesiyle öğretmenlerin çalg1 öğrenimi konusunda yüz yüze eğitim faaliyetleri düzenlenmesi, katılımlarının yüksek olması için teşvik edici çalışmalar yapılmas1, Millî Eğitim Bakanlı̆̆1 ile iş birliği sağlanarak hizmet içi kurs ve seminerlerin düzenlenmesi önerilmektedir. Bu eğitimlerde alanında uzman eğitimcilerin yer almasının çok önemli olduğu düşünülmektedir.

\section{Etik Beyan}

"Kocaeli Ilinde Görev Yapan Öğretmenlerin Mürị Dinleme Alş̧kanlkklarmnn İncelenmesi” başlıklı çalışmanın yazım sürecinde bilimsel kurallara, etik ve alıntı kurallarına uyulmuş; toplanan veriler üzerinde herhangi bir tahrifat yapılmamış ve bu çalışma herhangi başka bir akademik yayın ortamına değerlendirme için gönderilmemiştir. Etik kurul izni Kocaeli Üniversitesi Sosyal ve Beşeri Bilimler Etik Kurulu'nun 28/01/2021 tarih ve 2021/01 nolu toplantisinda alinan 22 sira sayll karar1 ile (Tarih: 28.01.2021, 4373 sayılı) alınmıştır.

\section{Kaynakça}

Atasoy, M. U. (2019). Öğretmen adaylarının müzik dinleme alışkanlıklarının değerlendirilmesi (Kütahya ili Örneği). Turkish Academic Research Review, 4(1), 221-234.

Anderson, W. T. (2016). Mindful music listening instruction increases listening sensitivity and enjoyment. Applications of Researcb in Music Education, 34(3), 48-55.

Çevik, S., Akın, A., Onuk, Ö. ve Yalçınkaya, B. (2003). Cumhuriyetin 80. yllında Gazi Üniversitesi gençliğinin yaşamında müziğin yeri ve işlevi. Malatya: Cumburiyetimiz̨in 80. Yullnda Mürik Sempozyumu, 36, 26-37.

De Vries, P. (2010). What we want: The music preferences of upper primary school students and the ways they engage with music. Australian Journal of Music Education, 1, 3-16.

Digital Age (2018). Türk insanının müzik dinleme alssskanlıkları ve dijital müziğin yükselişi. Digital Age Online Teknoloji ve Endïstri Dergisi, Çevrim içi adres: https://digitalage,com,tr/turk-insaninin-muzik-dinleme-aliskanliklari-vedijital-muzigin-yukselisi/ [Erişim tarihi: 15,12,2020].

Dobrota, S. ve Ercegovac, I. R. (2017). Music preferences with regard to music education, informal influences and familiarity of music amongst young people in Croatia. British Journal of Music Education, 34(1), 41-55.

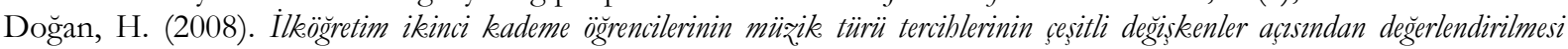
(Yüksek Lisans Tezi). Sakarya Üniversitesi Sosyal Bilimler Enstitüsü, Sakarya.

Doğan, U. (2020). Ortaöğretim öğrencilerinin müzik beğeni ve tercihlerinin çeşitli değişkenler yönünden incelenmesi (Sivas/Zara Örneği). Elektronik. Sosyal Bilimler Dergisi, 19(76), 1579-1600.

Dönmez, Y. E. ve İmik, Ü. (2020). Ferdi Tayfur örnekleminde Türk sinemasında arabesk müzik. İnönü Üniversitesi Kültuir ve Sanat Dergisi, 6(2), 135-148.

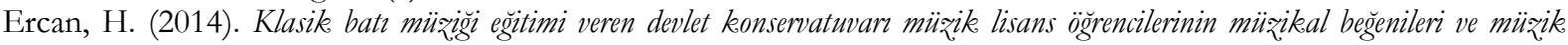
dinleme alşkeanlkelarmm incelenmesi (Yüksek Lisans Tezi). Abant İzzet Baysal Üniversitesi Eğitim Bilimleri Enstitüsü, Bolu. 
Erdal, G. G. (2007). Müziğin kişisel, toplumsal, ulusal, uluslararası işlevleri üzerine. Uluslararası Asya ve Kuzey Afrikea Calismalar Kongresi Bildirisi, 287-294.

Erdal, B. (2009). Müzik türlerinin tercih edilmesinde kişilik özellikleri ve beğeni ilişkisi (Doktora Tezi). Dokuz Eylül Üniversitesi Güzel Sanatlar Enstitüsü, İzmir.

Flowers, P. ve Murphy, J. (2001). Talking about music: interviews with older adults about their music education, preferences, activities, and reflections. Applications of Research in Music Education, 20(1), 26-32.

Güleç, K. S. (2009). Müziğin kişisel işlevleri açısından müzik eğitiminde güdülenmenin önemi. Uluslararası Asya ve Kuzey Afrika Çalışmaları Kongresi-ICANAS 38, Mürik Kültürü ve Eğitimi, Atatürk Kültür, Dil ve Tarih Yüksek Kurumu Yaymlar, 1(1), 365-375.

Güngör, N. (1993). Arabesk: Sosyo-kültürel açıdan arabesk mü̈ik (2. Basım). Ankara: Bilgi Yayınevi.

Gökbudak, Z. S. ve Gökbudak, R. (2003). İletişim fakültesi radyo-televizyon-sinema bölümü öğrencilerinin müziğe olan ilgileri. Selçuk İletișim, 3(1) 35-41.

Hui, F, W, V. (2001). Music preferences, music and non-music media use, and leisure involvement of Hong Kong adolescents. University Of North Texas.

İmik, Ü. (2007). Sosyal statünün mü̃ikesel beğeniye etkileri (Yüksek Lisans Tezi). Erciyes Üniversitesi Sosyal Bilimler Enstitüsü, Kayseri.

Karasar, N. (2013). Bilimsel araștırma yöntemi (25. Basım). Ankara: Nobel Yayın Dağıtım.

Kılıç, I. (2016). Ortaokul öğrencilerinin müzik ile ilgili görüşlerinin incelenmesi. Ë̆gitim ve Öğretim Araştırmalar Dergisi, 5(3), 360-371.

Oğuz, T. (2016). Dijital müzik tüketim alışkanlıkları. eKurgu, 24(1), 44-62.

Öz, N. B. (2001). İnsanın kültürel gelişiminde müzik eğitiminin önemi. Uludă̆ Üniversitesi Eğgitim Fakültesi Dergisi, 14(1), 101-106.

Özdemir, Ş. C. ve Can A. A. (2019). Müzikte dinleme, dinleme türleri ve müzik öğretmenliği öğrencilerinin müzik dinleme yaklașimları. Elementary Education Online, 18(1), 367-388.

Özen, C. (2016). Ögretmen adaylarmm mürik dinleme alşkanlıklar arasındaki farkllıklar (Yüksek Lisans Tezi). Gazi Üniversitesi Eğitim Bilimleri Enstitüsü, Ankara.

Özkasnaklı, U. ve Dalkıran E. (2017). Genel müzik eğitiminde çalg1 çalmaya yönelik öğrenci görüşleri: Denizli ili örneği. Sanat Ĕ̈itimi Dergisi, 5(1), 1-17.

Şahin Yıldırım, B. (2019). Sosyolojik açıdan mürik dinleme alışkanlıklarna etki eden etmenler: Bolu ili örneği (Yüksek Lisans Tezi). Abant İzzet Baysal Üniversitesi Sosyal Bilimler Enstitüsü, Bolu.

Taş, S. (2011). Simf ögretmeni adaylarmm klasik batı mǚiğine ilişkin tutumlar (Yüksek Lisans Tezi). Gazi Üniversitesi Eğitim Bilimleri Enstitüsü, Ankara

Tanrıkulu, N. (2011). Üniversite ögrencilerinin kulaklıkla müzik dinleme alıskanllklarmm işitme eşikleri üzerine etkisi: Başkent üniversitesi örneği (Yüksek Lisans Tezi). Başkent Üniversitesi Sağlık Bilimleri Enstitüsü, Ankara.

Türk Dil Kurumu. (2020). Ajitasyon tanımı, 12 Ocak 2021 tarihinde https:/ / sozluk.gov.tr/ adresinden erişildi.

Uçan, A. (2005). Genel müzik eğitiminde geleneksel müziklerimizin yeri ve önemine genel bir bakış. Yü̊üncü Yıl Üniversitesi 1. Ulusal Mü̃ile Ë̆itimi Semposyumu, Van.

Ulutürk, N. (2008). Anadolu güzel sanatlar lisesi müzile bölümü ögrencilerinin dinlemeyi tercib ettikleri müzik türleri (Yüksek Lisans Tezi). Abant İzzet baysal Üniversitesi Sosyal Bilimler Enstitüsü, Bolu.

Uslu, B. ve Göher, V. F. (2011). Müzik eğitimi A.B.D. öğrencileri ve müzik öğretmenlerinin müziksel beğenileri: Niğde ili örneği. Journal of New World Sciences Academy, 6(2), 250-260.

Woody, R. H. ve Burns, K. J. (2001). Predicting music appreciation with past emotional responses to music. Journal of Research in Music Education, 49(1), 57-70.

\section{EXTENDED ABSTRACT}

Teachers, the most important members of society, are the strongest actors in the upbringing of students. Creating a taste for music should include all brans teachers, not just music teachers. Teachers in different branches should play a role in the transfer of culture by including music in all their lives. As a result, teachers enable the society to develop in a multifaceted way. Education is thought to play an important role in the foundation and development of the habit of listening to music, which is shaped by the reflection of family, environment and popular factors. Examining the music listening habits of teachers, who have an important place in society, will shed light on the shaping of the musical life that future generations will turn to. Examining the musical lives of teachers from different regions of our country will enable us to have an idea about the musical life of the students they will train our next generations.

In this study, the research of music listening of teachers working in Kocaeli province was aimed. For this purpose, the types of music listened to, personal album archives, digital media album archives, elements they are influenced by the music they listen to, music listening tools, listening environment, instrument playing situations are questioned. The teacher is at the center of the quality of life and behavior 
and living spaces in society. Teachers are expected to carry their musical tastes on them as an example in their listening habits and aesthetic perspective lives. It is considered important to determine teachers' music preferences and listening habits at this hour. Kocaeli, Turkey's largest industrial city of the province is concentrated and intense as the one in different cultures in terms of immigration. Various studies have been conducted on the music preferences of teacher candidates and the experiences of scientists who question the music preferences of teachers working in the field have come to light. This situation led the researchers to question what the music listening habits of the teachers living in Kocaeli were. By establishing a connection with listening to music in terms of being a role model in education and being effective in the high lives of teachers from different branches of our country; It is thought that it can be effective on the transformation developments, cultural gains and tastes of teachers. Therefore, teachers' subject preferences and tendencies are important.

Descriptive survey method was used in this study to determine the music listening habits of teachers. In this direction, "Teachers' listening habits of music" questionnaire, consisting of 12 questions, was applied to determine the music listening habits of teachers, which was prepared by the researchers. Teachers working in Kocaeli constitute the universe of this research. Its sample consists of 421 teachers working in and different educational levels in Kocaeli. The demographic characteristics of the teachers participating in the study and the distribution of the quantitative data obtained regarding the findings related to the purpose of the study are presented in a table.

According to the research results; Teachers prefer listening to Pop Music in the first place and Turkish Folk Music in the second place. It has been observed that teachers make use of the developing technology and digital media to listen to music, and they mostly prefer smart phones as the phones turn into music players. In the selection of the instruments they played, it was observed that they preferred popular instruments and used in the music genres they listen to. It has been determined that, with the determination of the music listening habits of teachers, they become a determinant and role model in the listening habits of future generations, and this habit is shaped positively with education. The lifelong function of music and its function in education should be handled in a broad perspective, studies should be conducted to make sense of the relationship of music with other arts and disciplines, and programs should be organized in accordance with the branches. It is thought to be beneficial in terms of the development and cultural transfer of all branch teachers. It is recommended to create environments for listening and understanding music and to conduct guidance studies by field experts in order to gain the habit of listening to music in these environments. Teachers who incorporate music into their life can use it as a part of education by associating it with their own discipline. This situation may also contribute to the students' increasing their interest in music, their recognition of music genres, their tolerance and awareness of diversity, and their musical taste. In this sense, it is recommended that school administrations encourage teachers to work and create environments where teachers who play instruments can exhibit their performances in various activities. In order for teachers to connect with music in their educational activities, they should learn music by listening to works with rich harmonic infrastructure in concerts, which are the natural environment of music, as in mother tongue teaching. The individual can make listening in this way a part of his life. During listening, the important features of the work (rhythmic structure, instrumentation feature, polyphony, modal structure, etc.) can be highlighted and leave more permanent marks by drawing the attention of the audience to the desired feature. This situation can provide an understanding of music, it may be a factor in individuals' being selective in their music preferences and forming their own tastes.

When the results of the research are evaluated, it shows that music has an important place in the lives of teachers. Among the aims of the education, it is thought to create a musical taste, to ensure the development of music listening preferences on a scientific basis, to create an interested and curious audience profile who knows what and who listens. Habits can be shaped positively through education. 